\title{
Anti-Inflammatory Activity of Cinnamon Bark Oil (Cinnamomum Burmannii (Nees \& T. Nees) Blume) From Kerinci Regency of Indonesia
}

\author{
Budiastuti $^{1}$, Sukardiman $^{2}$, Riesta Primaharinastiti ${ }^{3}$, Rosy Dwi Nurcholida ${ }^{4}$ \\ \{diashelmi@yahoo.com ${ }^{1}$, maman_ht@yahoo.com², riesta-p-h@ff.unair.ac.id ${ }^{3}$, rosy.dwi.nurcholida- \\ 2015@ff.unair.ac.id $\left.{ }^{4}\right\}$ \\ Faculty of Pharmacy, Universitas Airlangga Surabaya, Indonesia ${ }^{1234}$
}

\begin{abstract}
Introduction: Cinnamomum burmannii (Nees \& T. Nees) Blume which has the main content of Cinnamaldehyde has an anti-inflammatory effect. Research on the antiinflammatory effect of the essential oil of the bark of C. burmannii from Kerinci Regency (CBOK) has been conducted. Methods: The anti-inflammatory test of CBOK was carried out using Wistar rats. The anti-inflammatory test was carried out by using the paw test. The volume increase in paw due to swelling were measured. Histopathological analysis was performed by counting inflammatory cells and expression of TNF- $\alpha$. The data analyzed were edema volume inhibition, the number of inflammatory cells and the expression of TNF- $\alpha$. Results: There was a significant difference in the increase in inhibition of edema in the administration of CBOK compared to the negative control. A decrease in the number of inflammatory cells and TNF- $\alpha$ expression were observed. Thus, in this study of CBOK has anti-inflammatory effects.
\end{abstract}

Keywords: Cinnamomum burmannii; anti-inflamatory; TNF- $\alpha$

\section{Introduction}

Cinnamomum burmannii (Nees \& T. Nees) Blume is native to Indonesia and mostly grows in the Kerinci area [1] (Ferry, 2013). The bark of C. burmannii is popularly called "cassiavera" or "Indonesian cassia" or "padang kaneel". Kerinci Regency is one of the largest Regency in developing cinnamon in Indonesia, in 2015 with a planted area of 40,962 ha and production value reached 52,980 tons $(64.92 \%)$ of the total national production [2] (Nurhayani, 2019). The high cinnamaldehyde content in cinnamon bark was expected to have anti-inflammatory effects [3,4,5,6] (Mendes, et al., 2016) (Gunawardena, et al., 2015) (Han \& Parker, 2017) (Mollazadeh \& Hosseinzadeh, 2016).

Research related to alternative medicines made from natural ingredients that can alleviate the effects of inflammation is important, especially in order to reduce unwanted side effects of anti-inflammatory drugs [7] (Ghasemian, et al., 2016). Inflammation is a normal protective response caused by injury or tissue infection and functions to fight microorganisms or foreign bodies that interfere with tissue and remove damaged or dead cells. The inflammatory response induces an increase in the permeability of the endothelial cell layer and the entry of inflammatory cells into the interstitium and the release of cytokines such as interleukins and tumor necrosis factor- $\alpha$ (TNF- $\alpha$ ) [8] (Kany, et al., 2019). 
Trans-cinnamaldehyde, the main component of the essential oil of the Cinnamomum species, has been studied to have anti-inflammatory effects. The high trans-cinnamaldehyde levels in cinnamon are expected to have anti-inflammatory effects [9] (Hosni, et al., 2017). This research was conducted using essential oil of C. burmannii bark from Kerinci Regency, Jambi Province, which is the main cinnamon producing district in Jambi Province, Sumatera. Standardization, specification and metabolite profile analysis of the essential oil of C. burmannii bark (CBOK) were carried out prior to the anti-inflammatory test.

Furthermore, the anti-inflammatory test was carried out with three doses. Antiinflammatory test was carried out in vivo with the paw test and histopathological observations to determine the effect of cinnamon essential oil on the number of inflammatory cells and expression TNF- $\alpha$ in edema tissue.

\section{Materials and Methods}

\subsection{Plant Material}

This research was conducted using essential oils from the bark of C. burmannii aged between 10 years and 12 years from Kerinci Regency which were harvested on May, 2018 and dried in an open space protected from direct sunlight to loos of drying (LOD) $<12 \%$. Identification was carried out by Indonesian Institute of Sciences (LIPI) Purwodadi Botanical Garden (No. 794/IPH.06/HM/V/2018) and has met the Indonesian Herbal Pharmacopoeia standard [10].

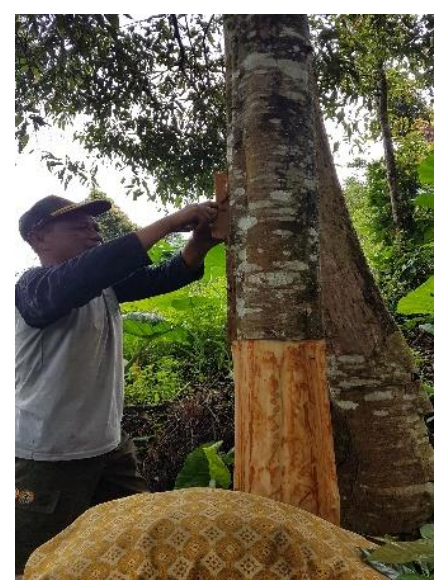

Fig1. Farmers were harvesting cinnamon bark in Kerinci

The chemicals are $\mathrm{NaCl}, \mathrm{Na} 2 \mathrm{SO} 4$, trans-Cinnamaldehyde $\geq 98 \%$ (Merck), dichloromethane (Merck), Carrageenan (Merck), Ibuprofen, Ketamine, xylazine base $20 \mathrm{mg}$ $/ \mathrm{mL}$ Xyla brand, $0.9 \%$ sodium cloride Intravenous Infusion B.P. Otsu-NS brand, formaldehyde buffer, TNF- $\alpha$ monoclonal antibody E-AB-22159 Elabscience Biotechnology Inc.

\subsection{Experimental Animals}

Male rat (Rattus novergicus) strain Wistar aged 3 months, body weight 180-220 g, healthy with indicators of clean hair, active movement, and clear eyes. Rats were obtained from the 
Pharmacology Laboratory of the Faculty of Medicine, Airlangga University. Ethical Permit Certificate obtained from the Faculty of Veterinary Medicine, Airlangga University No: 2.KE.075.05.2019.

\subsection{Essential Oil Distillation}

Essential oils are obtained by water and steam distillation. $3 \mathrm{~kg}$ of $C$. burmannii bark from Kerinci Regency, pounded with 8 mesh filters. The powdered cinnamon bark is then placed in the bath over the nest using 5 liters of separate water. The bath is assembled with a condenser, ensuring that there are no leaks and that circulation is fine. Distillate was collected for 6 hours, counted from the first drop distillate and carried out 3 times. The essential oil was separated from the water phase using a separating flask. Each liter of water phase was added 15 grams of $\mathrm{NaCl}$. The oil phase was then separated. The collected essential oil wa then added with anhydrous Na2SO4 to bind the water droplets [11] (Al-Dhubiab, 2012).

\subsection{Essential oil analysis}

The metabolite profile of essential 0il sample (CBOK) analysis was performed using the GC-MS Agilent 7890B GC and 5977B MSD with Agilent column 19091S-433UI HP-5ms Ultra Inert- $60^{\circ} \mathrm{C}-325^{\circ} \mathrm{C}$, column dimension $30 \mathrm{mx} 250 \mu \mathrm{m} \times 0.25 \mu \mathrm{m}$, run time $30 \mathrm{~min}$, injection volume $1 \mu \mathrm{L}$. Component identification was carried out by matching the mass spectra recorded with the mass spectrum standards from the National Institute of Standard and Technology Library (NIST05.LIB). The sample was diluted with methylene dichloride $(10 \mathrm{mg} / \mathrm{mL})$ and 1.0 $\mu \mathrm{L}$ was injected for analysis [12] (Li, et al., 2013).

\subsection{Anti-inflammatory activity test}

The male Wistar rats used during the study were prepared 1 week before the study began. The experimental animals were placed in optimal light, temperature and humidity conditions (light-dark cycle 12 hours, $27^{\circ} \mathrm{C} \pm 2{ }^{\circ} \mathrm{C}$, humidity $65-75 \%$ ), food and water provided ad libitum. 30 experimental animals that have met the requirements were divided into 5 groups; Each group consisted of 6 rats [13] (Lemeshow, et al., 1990). Each rat's left leg was given a permanent ink mark at lateral malleolus. Observations were started by measuring the paw volume of all experimental animals as volume $\mathrm{t}=0$. Group $1^{\text {st }}$ as a negative control was given oral $1 \% \mathrm{CMC}$ Na solution, group $2^{\text {sd }}$ as a positive control was given ibuprofen at a dose of $27 \mathrm{mg} / \mathrm{kg}$, Group $3^{\text {th }}, 4^{\text {th }}$, and $5^{\text {th }}$ were given CBOK at doses of 30,60 and $90 \mathrm{mg} / \mathrm{kg} \mathrm{BW}$ in $1 \%$ CMC-Na. After 30 minutes of treatment, experimental animals were injected with carrageenan $1 \% / 100 \mu \mathrm{L} /$ paw (0.9\% sterile $\mathrm{NaCl}$ carrier) using a needle size 26.

Furthermore, paw swelling measurements were carried out at 1, 2, 3, 4, and 5 hours using plethysmometer model 7141 UGO Basile SRI Italy [14.15] (Kostadinov, et al., 2014) (Phanse, et al., 2012). After measuring the volume of edema, the animals were sacrificed by injection of ketamine and xylazine. The left leg was cut and preserved in formaldehyde buffer liquid as material for making H\&E and IHC preparations Histological examination [16]. (Nile \& Park, 2013).

Histopathological examination to determine the number of inflammatory cells in the paw tissue by researchers and two anatomical pathologists. The number of inflammatory cells was counted using the Hematosillin and eosin staining techniques. Paw tissue was fixed in neutral buffered formalin, then embedded in paraffin, sliced (3-5 $\mu \mathrm{m})$ and stained with hematoxylin and eosin. The number of inflammatory cells was obtained by counting all the inflammatory cells found in the five fields of view at a magnification of 400x. All of these examinations use a 
Nikon H600L light microscope equipped with a 300-megapixel DS Fi2 digital camera and Nikkon Image System image processing software.

Examination of TNF- $\alpha$ expression using IHC staining method. Examination of TNF- $\alpha$ expression by two anatomical pathologists. This histopathological examination aims to determine the expression of TNF- $\alpha$ in the healing area of paw tissue semi-qualitatively according to the modified Remmele method [17] (Nowak, et al., 2007). The Remmele Scale Index (Immuno Reactive Score/IRS) was the result of multiplying the percentage of the immunoreactive cell score with the color intensity score on the immunoreactive cells. The IRS semiquantitative scale was the result of multiplying the positive cell percentage score (A) and the color reaction intensity score $(\mathrm{B}), \mathrm{IRS}=(\mathrm{A} \times \mathrm{B})$ using a Nikon H600L light microscope, equipped with a 300 megapixel DS Fi2 digital camera and Nikkon Image System image processing software at 1000x magnification [17] (Nowak, et al., 2007). Observations were made on five fields of view then an average percentage of the area was assessed

Table 1. Semi-quantitative Immunoreactive Score (IRS) scale

\begin{tabular}{ll}
\hline \multicolumn{1}{c}{ A } & \multicolumn{1}{c}{ B } \\
\hline Score 0 : No positive cells & Score 0 : No color reaction \\
Score 1 : Positive cells less than 10\% & Score 1:Weak yellowish color intensity \\
Score 2 : Positive cells range from 11\%-50\% & Score2: Medium color intensity (brown) \\
Score 3 : Positive cells range from 51\%-80\% & $\begin{array}{l}\text { Score3 : Strong color intensity (dark } \\
\text { brown) }\end{array}$ \\
\hline Score 4: Positive cells more than $80 \%$ & \\
\hline
\end{tabular}

\subsection{Statistic analysis}

The statistical evaluation of the anti-inflammatory activity testing method was carried out by one-way analysis of variance (ANOVA). Statistical significance was expressed as $\mathrm{P}<0.05$. Data were analyzed using the independent sample t-test of SPSS 24.0 software product. ShapiroWilk test to determine data normality and Levene test to determine homogeneity of data on edema inhibition data. If the data was normally distributed and homogeneous, it was continued with the ANOVA test with a confidence level of $95 \%$. The number of inflammatory cells and TNF- $\alpha$ expression were analyzed using the Kruskal-Wallis test [18].

\section{Result and Discussion}

\subsection{Essential Oil Distillation}

The results of water and steam distillation from $C$. burmannii bark has a lighter yellow color than the color of the trans-cinnamaldehyde marker compound. The results of the distillation of C.burmannii bark powder are listed in Table 2. 
Table 2.Specifications of C.burmannii bark Oil from Kerinci (CBOK)

\begin{tabular}{llllll}
\hline & $\begin{array}{c}\text { Rendement } \\
\%\end{array}$ & Organoleptic & $\begin{array}{c}\text { Specific } \\
\text { gravity }\end{array}$ & $\begin{array}{c}\text { Refractive } \\
\text { Index }\end{array}$ & $\begin{array}{c}\text { Trans- } \\
\text { Cinnamaldehyd } \\
\text { e Content (\%) }\end{array}$ \\
\hline Essetial & $0.8011 \pm 0.04$ & $\begin{array}{l}\text { Clear yellow } \\
\text { color, distinctive } \\
\text { odor (smell like } \\
\text { cinnamaldehyde) }\end{array}$ & $\begin{array}{l}1.0512 \pm \\
\text { 72 }\end{array}$ & $1.5713 \pm 0.0$ & $43.990 \pm 3.932$ \\
& & & 041 & \\
\hline
\end{tabular}

The Indonesian Herbal Pharmacopeia (FHI) requirement for the essential oil content of cinnamon bark is not less than $0.42 \%$ v/w [10]. Indonesian national standards (SNI no. 06-37342006) requirements for the $C$. burmannii bark oil are specific gravity $1.008-1.030$, refractive index $1.559-1.595$ and cinnamaldehyde not less than $0.50 \%$.

\subsection{Metabolite Profiles of CBOK}

The result of water and steam distillation of $\mathrm{CBOK}$ produces pale yellow oil with a distinctive odor and yield of $08011 \% \pm 0.0472(\mathrm{v} / \mathrm{w})$ based on dry weight. Figure 1 shows the CBOK gas chromatogram. 41 the components identified in CBOK. The composition of CBOK is shown in Table 3. The main compound of CBOK is trans-cinnamaldehyde, which is considered as the most dominant one [19] (Budiastuti, et al., 2020). The other main components are Linalool, Benzen propanal, Copaene, Cinamyl ester Acetic acid, $\gamma$-Muurolene, Trans- $\alpha$ Bergamotene and $\alpha$-Terpineol.

\subsection{Edema inhibition analysis}

The increase in paw volume (edema) average $50,03 \%$ from the initial volume is due to carrageenan which induces inflammation. The maximum volume of edema was observed in the negative control group at about three hours after carrageenan injection. The effect of inhibition of edema in paw occurred in the administration of ibuprofen or CBOK indicated by a decrease in the volume of edema in the administration of ibuprofen and the administration of $\mathrm{CBOK}$ at doses of $60 \mathrm{mg} / \mathrm{kg} \mathrm{BW}$ and $90 \mathrm{mg} / \mathrm{kg} \mathrm{BW}$ (Table 4). CBOK at doses of $60 \mathrm{mg} / \mathrm{kg}$ and $90 \mathrm{mg} / \mathrm{kg}$ showed paw edema inhibition activity at 1,2,3,4 and 5 hours after carrageenan induction.

\section{IC $_{50}$ Value Calculation}

The results of the calculation of the $\mathrm{IC}_{50}$ value of essential oil from Kerinci:

$$
\begin{aligned}
& y=0.6553 x+4.4866 \\
& 50=0.6553 x+4.4866 \\
& x=(50-4.49) / 0.66 \\
& x=69.45
\end{aligned}
$$

Table 3. GC-MS analysis of the composition of CBOK

\begin{tabular}{lll}
\hline No. & Compound name & \% Relative \\
\hline $\mathbf{1}$ & Benzaldehyde & 1.35 \\
$\mathbf{2}$ & Eucalyptol & 1.46 \\
$\mathbf{3}$ & Linalool & 7.13 \\
$\mathbf{4}$ & Benzenepropanal & 4.04 \\
$\mathbf{5}$ & endo-Borneol & 0.44 \\
$\mathbf{6}$ & Terpinen-4-01 & 0.62 \\
$\mathbf{7}$ & $\alpha$-Terpineol & 1.24 \\
$\mathbf{8}$ & trans-Cinnamaldehyde & 46.77
\end{tabular}




\begin{tabular}{|c|c|c|}
\hline 9 & Bornyl acetate & 1.3 \\
\hline 10 & (E) 3-phenyl-2-Propen-1-01 & 0.37 \\
\hline 11 & Hydrocinamic acid & 0.23 \\
\hline 12 & 2-Carene & 0.38 \\
\hline 13 & Eugenol & 0.66 \\
\hline 14 & 1,2,4-Metheno-1H-indene & 0.33 \\
\hline 15 & Ylangene & 1.09 \\
\hline 16 & Copaene & 3.18 \\
\hline 17 & Aromadendrene & 0.39 \\
\hline 18 & trans- $\alpha$-Bergamotene & 0.30 \\
\hline 19 & Caryophyllene & 6.52 \\
\hline 20 & cinamyl ester Acetic acid & 2.01 \\
\hline 21 & 1H-Cycloprop(e)azulene & 0.62 \\
\hline 22 & Humulene & 0.91 \\
\hline 23 & $\gamma$-Muurolene & 3.02 \\
\hline 24 & 1,2,3,4,4a,5,6,8a-octahydronaphthalene & 0.65 \\
\hline 25 & $\alpha$-Muurolene & 3.55 \\
\hline 26 & 1-(1,5-dimethyl-4-hexenyl)-4-methyl-Benzene & 0.83 \\
\hline 27 & 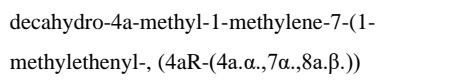 & 0.29 \\
\hline & Naphthalene & \\
\hline 28 & 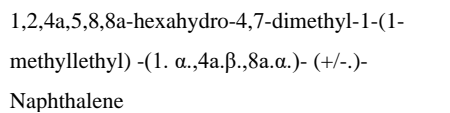 & 0.28 \\
\hline 29 & $\beta$-Bisabolene & 0.63 \\
\hline 30 & $\begin{array}{l}\text { 1,2,3,5,6,8a-hexahydro-4,7-dimethyl-1-(1- } \\
\text { methylethyl) -(1S-cis)-Naphthalene }\end{array}$ & 3.55 \\
\hline 31 & $\begin{array}{l}\text { 4- Isopropyl-6-methyl-1-methylene-1,2,3,4- } \\
\text { tetrahydronaphthalene }\end{array}$ & 0.80 \\
\hline 32 & Caryophyllene Alcohol & 0.42 \\
\hline 33 & Caryophyllenyl oxide & 2.54 \\
\hline 34 & Tetradecanal & 0.50 \\
\hline 35 & 1-ethyl-5-methyl-Pyrazole-4-carboxaldehyde & 0.29 \\
\hline 36 & 2-Acetyl-6-methoxynaphthalene & 0.27 \\
\hline 37 & $\tau$-Cadinol & 0.67 \\
\hline 38 & Isoelemicin & 0.32 \\
\hline 39 & Di-epi-1,10-cubenol & 0.31 \\
\hline 40 & $\alpha$-Cadinol & 0.67 \\
\hline 41 & cis-, $\alpha$.-Copaene-8-ol & 0.31 \\
\hline
\end{tabular}

Table 4. Mean Percentage of paw edema inhibition in each group

\begin{tabular}{|c|c|c|c|c|c|c|}
\hline \multirow{3}{*}{ Group } & \multicolumn{6}{|c|}{ Mean percentage of edema inhibition } \\
\hline & & & & $(\%)$ & & \\
\hline & $\mathbf{0}$ & 1 & 2 & 3 & 4 & 5 \\
\hline Negative Control & 0 & 0 & 0 & 0 & 0 & 0 \\
\hline $\begin{array}{l}\text { Ibuprofen } \\
27 \mathrm{mg} / \mathrm{kg}\end{array}$ & 0 & $40,00 \pm 10,74$ & $30,11 \pm 7,87$ & $71,8 \pm 5,17$ & $77,67 \pm 3,47$ & $88,14 \pm 3,58$ \\
\hline
\end{tabular}




\begin{tabular}{ccccccc} 
CBO from Kerinci & & & & & \\
$30 \mathrm{mg} / \mathrm{kg}$ & 0 & $7,27 \pm 3,86$ & $4,69 \pm 3,30$ & $29,83 \pm 7,06$ & $46,48 \pm 6,78$ & $58,90 \pm 5,98$ \\
CBO from Kerinci & & & & & & \\
$60 \mathrm{mg} / \mathrm{kg}$ & 0 & $16,59 \pm 6,98$ & $21,18 \pm 3,74$ & $34,29 \pm$ & $74,64 \pm 8,15$ & $86,76 \pm 6,37$ \\
CBO from Kerinci & & & & & & \\
$90 \mathrm{mg} / \mathrm{kg}$ & 0 & $33,86 \pm 3,53$ & $26,63 \pm 4,75$ & $70,70 \pm$ & $78,88 \pm 12,16$ & $88,83 \pm 7,58$ \\
\hline
\end{tabular}

\subsection{Observation of inflammatory cells and TNF- $\alpha$ expression}

The results showed that the number of inflammatory cells and TNF- $\alpha$ at the CBOK dose of $60 \mathrm{mg} / \mathrm{kg} \mathrm{BW}$ and $90 \mathrm{mg} / \mathrm{kg}$ BW decreased. The administration of $30 \mathrm{mg} / \mathrm{kg} \mathrm{BW}$ has not shown a decrease in inflammatory cells and TNF- $\alpha$ expression (Fig.3 and 4, Tables 5 and 6).

Table 5. The number of inflammatory cells was given 3 doses of CBOK

\begin{tabular}{lc}
\hline Groups & Amount of Inflammatory Cells/5Field of Vieu \\
\hline $30 \mathrm{mg} / \mathrm{kg}$ bb CBOK & $985 \pm 45.4$ \\
$60 \mathrm{mg} / \mathrm{kg}$ bb CBOK & $279.67 \pm 94.09$ \\
$90 \mathrm{mg} / \mathrm{kg}$ bb CBOK & $360.33 \pm 127.45$ \\
Positive Control (Ibuprofen) & $399.67 \pm 187.73$ \\
Control Negative & $713 \pm 93.74$ \\
\hline
\end{tabular}

Table 6.TNF- $\alpha$ Value Calculation

\begin{tabular}{lc}
\hline \multicolumn{1}{c}{ Groups } & Score \\
\hline Negative control & $10.7 \pm 1.30$ \\
Ibuprofen $27 \mathrm{mg} / \mathrm{kg} \mathrm{BW}$ & $10.5 \pm 0.58$ \\
CBOK $30 \mathrm{mg} / \mathrm{kg} \mathrm{BW}$ & $11.6 \pm 0.69$ \\
CBOK $60 \mathrm{mg} / \mathrm{kg} \mathrm{BW}$ & $9.0 \pm 2.57$ \\
CBOK $90 \mathrm{mg} / \mathrm{kg} \mathrm{BW}$ & $10.4 \pm 0.92$ \\
\hline
\end{tabular}

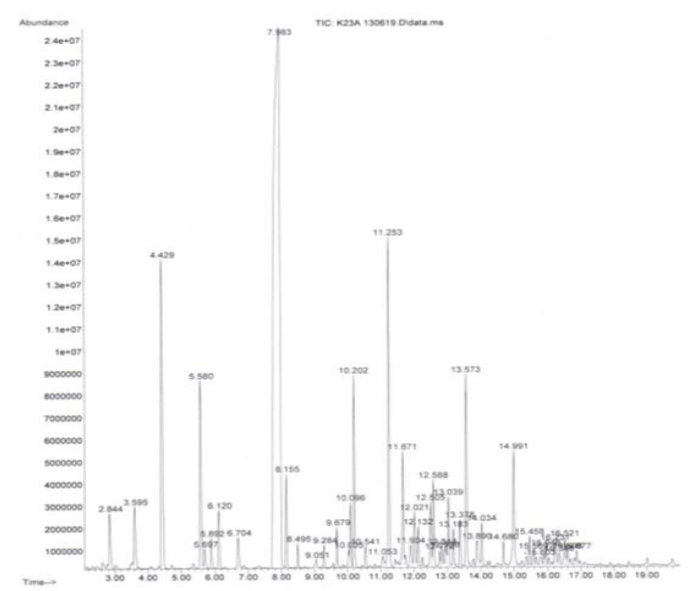

Fig.1. Secondary metabolite components of C.burmannii bark Oil from Kerinci using GC-MS 


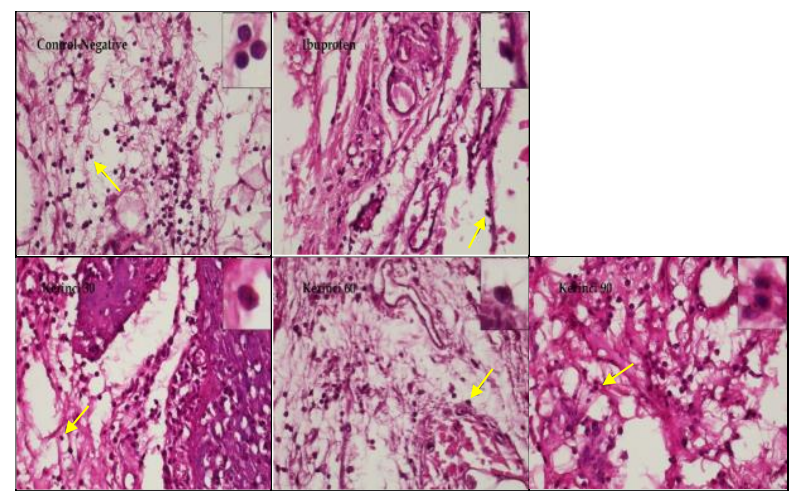

Fig 2. Photomicrographs of the histopathological analysis of paw tissue: negative control; Ibuprofen; CBOK $30 \mathrm{mg} / \mathrm{kg}$, CBOK $60 \mathrm{mg} / \mathrm{kg}$, CBOK90 mg/kg Hematocyilin and Eosin staining, 400x magnification; Nikon H600L microscope; 300-megapixel DS Fi2 camera.

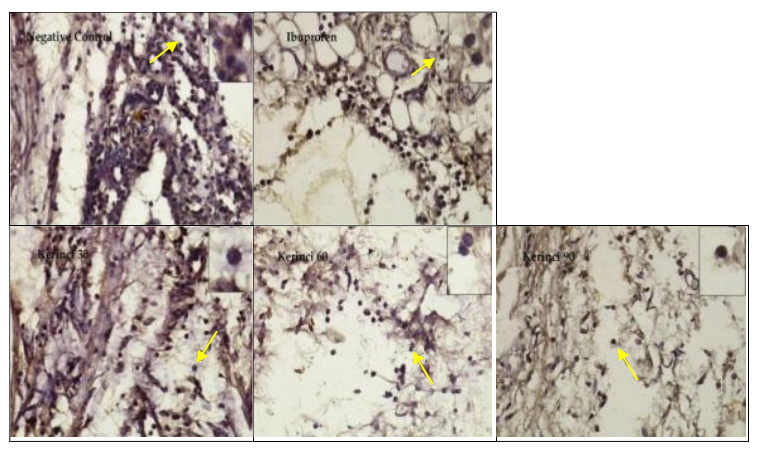

Fig 3. Comparison of TNF- $\alpha$ expression between treatments: negative control, Ibuprofen/positive control, CBOK $30 \mathrm{mg} / \mathrm{kg}$, CBOK $60 \mathrm{mg} / \mathrm{kg}$, CBOK $90 \mathrm{mg} / \mathrm{kg}$, (Inlet:

shows TNF- $\alpha$ expression represented by chromogenic brown color in the nucleus and cytoplasm of macrophage cells) (immunohistochemical staining, $1000 \mathrm{x}$ magnification; Nikon H600L microscope; 300-megapixel DS Fi2 camera).

\section{Discussion}

Kerinci Regency is the largest producer of cinnamon in Indonesia. The yield of essential oil from the distillation of C. burmannii bark was $0.8011 \pm 0.0472$. CBOK contains $43.990 \pm 3.932$ trans-Cinnamaldehyde and a specific gravity of $1.0512 \pm 0.0015$. Essential oils, which are complex mixtures of volatile compounds consisting of a complex mixture of more than 300 different compounds consisting mainly of terpenes which are bio generated by the mevalonic pathway. These molecules include monoterpenes, sesquiterpenes. also contains phenolic compounds, which are derived via the shikimate pathway.

The chemical composition of essential oils has many biological activities (antioxidant, antiinflammatory, antimicrobial, etc [20, 21] (Dhifi, et al., 2016) (Kosmides, et al., 2013). In this study CBOK was detected 41 different compounds. Actually, many components were not 
detected because of the small amount. Essential oil production depends not only on genetic factors and the stage of plant development, but also on environmental factors that can produce biochemical and physiological changes in plants that change the quantity and quality of essential oils[22] (Prins, et al., 2010)

The maximum volume of edema was observed in the negative control group at three hours after carrageenan injection. The carrageenan-induced inflammatory reaction developed in the form of edema with an increase in paw volume up to $50,03 \%$ of the initial volume. The inflammation that occurred in this study was caused by carrageenan. Exudation due to increased vascular permeability was a major cause of acute inflammation. There was inhibition of edema when administering $\mathrm{CBOK}$ at doses of $30,60,90 \mathrm{mg} / \mathrm{kg}$ and ibuprofen $27 \mathrm{mg} / \mathrm{kg} \mathrm{BW}$. At doses of 60 and $90 \mathrm{mg} / \mathrm{kg}$ CBOK showed edema inhibitory activity at 1, 2, 3, 4, and 5 hours. Inflammation serves to avoid injury which in turn will damage cells and body tissues.

The maximum swelling rate in the paw injected with carrageenan was reached about three hours after carrageenan administration. The maximum swelling volume was reduced with CBOK and ibuprofen. Inhibition of edema was seen from the first hour of CBOK administration at doses of $60 \mathrm{mg} / \mathrm{kg}$ and $90 \mathrm{mg} / \mathrm{kg} \mathrm{BW}$. The results of the normality and homogeneity test data on the percentage of edema inhibition at 1 to 5 hours after carrageenan induction had a $p$ value> 0.05 . This shows that the standard residual value of the observed data was normally distributed. The percentage of inhibition of edema at 1 to 5 hours has a p value $>0.05$ which indicates that the data is homogeneous. The results of statistical calculations of multiple comparisons one way ANOVA percentage of inhibition at 1 to 5 hours at a dose of $30 \mathrm{mg} / \mathrm{kg}, 60 \mathrm{mg} / \mathrm{kg} \mathrm{BW}$ and 90 $\mathrm{mg} / \mathrm{kg} \mathrm{BW}$ showed a significance value $<0.05$, meaning that there was a significant difference between the doses of $30 \mathrm{mg} / \mathrm{kg}$ with $60 \mathrm{mg} / \mathrm{kg}$ and $90 \mathrm{mg} / \mathrm{kg} \mathrm{BW}$. The result of IC50 calculation shows that CBOK was able to do $50 \%$ resistance to edema. The IC50 CBOK value was $69.45 \mathrm{mg} / \mathrm{kg} \mathrm{BW}$.

Inflammatory cell count and TNF- $\alpha$ expression were observed as indicators of inflammatory response in addition to observations of inhibition of edema. The inflammatory response begins with the release of inflammatory cells, namely basophils, eosinophils, neutrophils, and some monocytes due to increased vascular permeability that occurs due to contraction and separation of endothelial cells. Analysis of inflammatory cells on H\&E tissue staining preparations, namely the paw tissue injected with carrageenan. The negative control group showed an accumulated infiltration of inflammatory cells (Fig.3).

Previously, experimental animals treated with CBOK or ibuprofen had a decreased number of inflammatory cells compared to controls. The dose given also has an effect on improving inflammatory conditions, it appears that the CBOK dose of $30 \mathrm{mg} / \mathrm{kg} \mathrm{BW}$ has not shown a decrease in the number of inflammatory cells. In administering CBOK at a dose of $60 \mathrm{mg} / \mathrm{kg}$ $\mathrm{BW}$ and $90 \mathrm{mg} / \mathrm{kg} \mathrm{BW}$, the number of inflammatory cells was relatively lower than that of negative controls. TNF- $\alpha$ expression showed a decrease in the preparations given CBOK or ibuprofen. Carrageenan is a chemical that is effective in releasing inflammatory and proinflammatory mediators (prostaglandins, leukotrienes, histamine, bradykinin, TNF- $\alpha$, etc.) [23] (Amdekar, et al., 2012).

Tumor necrosis factor- $\alpha$ (TNF- $\alpha)$ is a pro-inflammatory cytokine involved in the formation and continuation of the inflammatory process [24] (Rocha, et al., 2006). The data obtained from this study suggest that CBOK can inhibit the increased volume of edema. This indicates a prostaglandin inhibition. Prostaglandins that induce vasodilation and increase vascular permeability. Macrophages release cytokines (IL-1, IL-6, TNF- $\alpha$ ) which cause local and systemic changes. IFN $-\gamma$ and TNF- $\alpha$ activate macrophages to enhance phagocytosis [25] (Adenin, 2019). The histopathological features of the paw assessed by IHC staining the TNF- $\alpha$ 
expression read can indicate the severity of inflammation. Decreased TNF- $\alpha$ expression can be used as an indicator of decreasing the severity of inflammation.

The greatest expression of TNF- $\alpha$ was in the negative control group. Improvements in the histopathological image of paw tissue preparations assessed based on TNF- $\alpha$ expression were seen in the group that received ibuprofen as a positive control and the group that was given CBOK. Trans-Cinnamaldehyde can suppress the production of proinflammatory cytokines [9] (Hosni, et al., 2017).

In general, CBOK administration shows a decrease in the number of inflammatory cells and the expression of TNF- $\alpha$. A decrease in edema volume, a decrease in the number of inflammatory cells and a decrease in TNF- $\alpha$ expression can be data that can be used as indicators that the administration of CBOK has an anti-inflammatory effect. Inhibition of TNF- $\alpha$ release may reduce the severity of inflammation [26] (Joshi, et al., 2010). Research on 2hydroxycinnamaldehyde from Cinnamomum cassia showed an inhibitory effect on nitric oxide production by inhibiting the activation of factor NF- $\kappa$ B [27] (Rao \& Gan, 2014). Thus, CBOK has been shown to have an acute anti-inflammatory effect on rats.

There was a significant difference in the increase in inhibition of edema in the administration of CBOK with a dose of $60 \mathrm{mg}$ and $90 \mathrm{mg}$ compared to the negative control. A decrease in the number of inflammatory cells and expression of TNF- $\alpha$ were also observed in edema tissue. C. burmannii barks oil from Kerinci Regency has the properties of inhibiting edema in inflammation, reducing the number of inflammatory cells and reducing the expression of TNF- $\alpha$. This is consistent with previous studies that cinnamaldehyde and linalool play an important role as active constituents in essential oils for the prevention of LPS-induced inflammation [28, 29] (Lee, et al., 2018), (Liao, et al., 2012).

\section{Conclusion}

The administration of CBOK with a dose of $60 \mathrm{mg}$ and $90 \mathrm{mg}$ have impact on decreasing the inflamatory cells. Therefore, it can be concluded that CBOK has properties to inhibit inflamation. Thus, in this study of C. burmanniibark oil from Kerinci Regency of Indonesia has anti-inflammatory effects on wistar rats.

\section{Acknowledgment}

The authors are grateful to Kementrian Riset, Teknologi dan Pendidikan Tinggi Indonesia, Doctoral Dissertation Research in Fiscal Year 2019 Grant No: 1520/UN3/2019.

\section{References}

[1] Ferry, Y. Development Prospects of Cinnamon Plant. SIRINOV, Vol 1, No 1, April 2013 ( Hal : $11-20), 1(1), 11-20,(2013$, April).

[2] Nurhayani, R. Guncangan Harga dan Pangsa Pasar Ekspor Kayu Manis Kabupaten Kerinci. Jurnal Sains Sosio Humaniora, Volume 3 (2), 189-197, (2019, Des).

[3] Mendes, S., Sousa, F., Pereira, D., Ferro, T., Pereira, I., Silva, B., \& Pinheiro, A. Cinnamaldehyde modulates LPS-induced systemic inflammatory response syndrome through TRPA1-dependent and independent mechanisms. International Immunopharmacology, 34, 60-70. doi: 10.1016/j.intimp.2016.02.012, (2016).

[4] Gunawardena, D., Karunaweera, N., Lee, S., Kooy, F. v., Harman, D., Raju, R., . . Mü, G. Antiinflammatory Activity of Cinnamon (C. zeylanicum and C. cassia) Extracts -identification of E- 
cinnamaldehyde and O-methoxy cinnamaldehyde As the Most Potent Bioactive Compounds. The Royal Society of Chemistry. doi:10.1039/c4fo00680a, (2015).

[5] Han, X., \& Parker, T. Antiinflammatory Activity of Cinnamon (Cinnamomum zeylanicum) Bark Essential Oil in. Phytotherapy Research, 31, 1034-1038. doi:10.1002/ptr.5822, (2017).

[6] Mollazadeh , H., \& Hosseinzadeh, H. Cinnamon effects on metabolic syndrome: a review based on its mechanisms. Iranian Journal of Basic Medical Sciences, 19(12), 1258-1270. doi:10.22038/ijbms.2016.7906. (2016, Dec).

[7] Ghasemian, M., Owlia, S., \& Owlia, M. Review of Anti-Inflammatory Herbal Medicines.Advances in Pharmacological Sciences Volume, 1(Article ID 9130979), 1-11. doi:0.1155/2016/9130979, (2016, January).

[8] Kany, S., Vollrath, J., \& Relja, B. Cytokines in Inflammatory Disease. Int. J. Mol. Sci., 20(6008), 1-31. doi:10.3390/ijms20236008, (2019, Nov 28).

[9] Hosni, A., Abdell-Moneim, A., Abdel-Reheim, E., Mahammed, S., Hel, \& Helmy, H. Cinnamaldehyde Potentially Attenuates Gestational Hyperglycemia in Rats Through Modulation of PPAR $\gamma$, Proinflammatory cytokines and oxidative stress. Biomedicine Pharmacotherapy, 88, 52-60. doi: 10.1016/j.biopha.2017.01.054, (2017, April 1).

[10] Kementrian Kesehatan Republik Indonesia, Farmakope Herbal Indonesia. II ed. Jakarta (Jakarta): Kementrian Kesehatan Republik Indonesia, [2017].

[11] Al-Dhubiab, B. Pharmaceutical Applications and Phytochemical Profile of Cinnamomum burmannii. Pharmacogn Review, 6(12), 125-131. doi:10.4103/0973-7847.99946, (2012, Jul-Dec).

[12] Li, Y.-Q., Kong, D.-X., \& Wu, H. Analysis and evaluation of essential oil components of cinnamon barks using GC-MS and FTIR spectroscopy. Industrial Crops and Products, 41, 269-278. doi: 10.1016/j.indcrop.2012.04.056, (2013).

[13] Lemeshow, S., David, W., Hosmer, J., Klar, J., \& Lwanga, S. Adequacy of Sample Size in Health Studies. Baffins Lane, Chichester: John Wiley \& Sons, (1990).

[14] Kostadinov, I., Delev, D., Petrova, A., Stanimirova, I., Draganova, K., Kostadinova, I., \& Murdjeva, M. Study on Anti-inflammatory and Immunomodulatory Effects of Clomipramine in Carrageenan and Lipopolysaccharide-induce Rat Models of nflamation. Biotechnology \&Biotechnological Equipment, 28(3), 552-558. Retrieved from https://www.tanfonline.com/loi/tbeq20, (2014, Sep 25)

[15] Phanse, M., Patil, M., Abbulu, K., Chaudhari, P., \& Patel, B. In-vivo and in-vitro screening of medicinal plants for their anti-inflammatory activity: an overview. Journal of Applied Pharmaceutical Science, 02 (07), 19-33. doi:10.7324/JAPS.2012.2704, (2012).

[16] Nile, S., \& Park, S. Optimized Methods for In Vitro and In Vivo Anti-Inflammatory Assays and Its Applications in Herbal and Synthetic Drug Analysis. Mini-Reviews in Medicinal Chemistry, 13, 95-100. doi:10.2174/138955713804484712, (2013).

[17] Nowak, M., Made, J., \& Dziegiel, P. Intensity of COX2 Expression in Cells of Soft Tissue Fibrosarcomas in Dogs as Related to Grade of Tumour Malignancy. Bull Vet Inst Pulawy, 51, 275 279, (2007).

[18] Rohman, A., Statistika dan Kemometrika Dasar dalam Analisis Farmasi. Yogyakarta: Pustaka Pelajar (2014).

[19] Budiastuti, Andini, Y., Cahya, I., Primaharinastiti, R., \& Sukardiman. (2020, May-June). Standardization Bark of Cinnamomum burmannii Nees Ex Bl. from Five Areas of Indonesia. Pharmacogn J., 12(3), 578-588. doi:10.5530/pj.2020.12.87, (2020).

[20] Dhifi, W., Bellili, S., Jazi, S., Bahloul, N., Mnif, W., September 22). Essential Oils' Chemical Characterization and Investigation of Some Biological Activities: A Critical Review. Medicines, 3(25). doi:10.3390/medicines3040025, (2016).

[21] Kosmides, A., Kamisoglu, K., Calvano, S., Corbett, S., \& Androulakis, I. (2013). Metabolomic Fingerprinting: Challenges and Opportunities. Crit Rev Biomed Eng, 41(3), 205-221. Retrieved from https://www.ncbi.nlm.nih.gov/pmc/articles/PMC4096240/, (2013).

[22] Prins, C., Vieira, I., \& Freitas, S. Growth regulators and essential oil production. Braz. J. Plant Physiol, 22(2), 91-102. (2010). 
[23] Amdekar, S., Roy, P., Singh, V., Kumar, A., Singh, R., \& Sharma, P. Anti-Inflammatory Activity of Lactobacillus on Carrageenan-Induced Paw Edema in Male Wistar Rats. International Journal Inflamation, 2012, 752015. doi:10.1155/2012/752015, (2012).

[24] Rocha, A., Fernandes, E., Quinta, N., Campos, M., \& Calixto, J. Relevance of Tumour Necrosis Factor-a for the Inflammatory and Nociceptive Responses Evoked by Carrageenan in the Mouse Paw. British Journal of Pharmacology, 148(5), 688-695, (2006).

[25] Adenin, I. Peran Komponen Inflamasi Akibat Insersi Alat Kontrasepsi dalam Rahim dan Hubungannya dengan Peningkatan Kadar Glikodelin A. eke, 7(2), 156-161. doi:10.23886/ejki.7.11123, (2019, Agustus).

[26] Joshi, K., Awte, S., Bhatnagar, P., Walunj, S., Gupta, R., Joshi, S., Bani, S. Cinnamomum zeylanicum Extract Inhibits Proinflammatory Cytokine TNF $\mu$ : in vitro and in vivo Studies. Research In Pharmaceutical Biotechnology, 2(2), 14-21. Retrieved from http://www.academicjournals.org/RPB, (2010, April).

[27] Rao, P., \& Gan, S. Cinnamon: A Multifaceted Medicinal Plant. Evidence-Based Complementary and Alternative Medicine, 1-12. doi:10.1155/2014/642942, (2014).

[28] Lee, S.-C., Wang, S.-Y., \& Li, C.-C. Anti-inflammatory effect of cinnamaldehyde and linalool from the leaf essential oil of Cinnamomum osmophloeum Kanehira in endotoxin-induced mice. $\mathrm{j}$ o u r n a 1 of food and drug a $n$ a 1 y s i s, 26, 211-220. doi: 10.1016/j.jfda.2017.03.006, (2018, January).

[29] Liao, J.-C., Deng, J.-S., Chiu, C.-S., Huang, S.-S., Shie, P.-H., \& Huang, G.-J. Anti-Inflammatory Activities of Cinnamomum cassia Constituents In Vitro and In Vivo. Evidence-Based Complementary and Alternative Medicine. doi: doi:10.1155/2012/429320, (2012). 